\title{
Thermalstabilization of chitinolytic enzymes of Pantoea dispersa
}

\author{
Gohel $\mathrm{V}^{1,2}$ and Naseby $\mathrm{DC}^{1^{*}}$ \\ ${ }^{1}$ School of Life Sciences, Faculty of Health and Human Science, University of \\ Hertfordshire, College Lane, Hatfield, Herts, AL10 9AB, UK \\ ${ }^{2}$ Department of Microbiology and Biotechnology Centre, Faculty of Science, M.S. \\ University of Baroda, Vadodara - 390 002, Gujarat, India
}

*Corresponding author. Tel.: + 44-(0)1707284397; Fax: + 44-(0)1707284115

Email address:d.c.naseby@herts.ac.uk (D.C.Naseby) 


\begin{abstract}
The thermodynamic deactivation kinetics, $\Delta \mathrm{H}^{*}, \Delta \mathrm{S}^{*}, \mathrm{E}$ and $\Delta \mathrm{G}^{*}$ were used to understand the stability behaviour of the novel chitinases (I, II and III) of the marine isolate Pantoea dispersa in a range of salts and varying $\mathrm{pH}$ conditions ( $\mathrm{pH} 4$ to 9). The deactivation rate decreased with increasing half life of chitinase I, II and III in the presence of salts at 30$60^{\circ} \mathrm{C}$ with the following effect on the order of stability evident $\mathrm{NaCl}>\mathrm{KH}_{2} \mathrm{PO}_{4}>\mathrm{KBr}>\mathrm{NH}_{4} \mathrm{NO}_{3}>\mathrm{KNO}_{3}>\mathrm{MgSO}_{4} .7 \mathrm{H}_{2} \mathrm{O}>\mathrm{CaCl}_{2}$. With increasing $\mathrm{pH}$ the deactivation rate decreased whilst the half life of chitinase I, II and III increased. This lead to increased stability at high $\mathrm{pH}$ 's with the following order of stability evident $9 \geq$ $8>7>6>5>4$ at $30-60^{\circ} \mathrm{C}$. With increasing pH's and addition of each salt $\Delta H^{*}$ of chitinase I, II and III increased whilst deactivation energy decreased. Furthermore $\Delta S^{*}$ was found to be comparatively lower than untreated chitinase I, II and III. The free energy of chitinase I, II and III decreased with increasing $\mathrm{pH}$ and different salts in the same order as described above. The greater stability of chitinase I ( $\mathrm{t}_{1 / 2}: 270,225,185$ and $\left.135 \mathrm{~min}\right)$, II $\left(\mathrm{t}_{1 / 2}: 225,210,195\right.$ and $\left.135 \mathrm{~min}\right)$ and III $\left(\mathrm{t}_{1 / 2}: 210,150,120\right.$ and $\left.105 \mathrm{~min}\right)$ at $30-60^{\circ} \mathrm{C}$ respectively were observed at $\mathrm{pH}$. With the addition of $\mathrm{NaCl}$, the following stabilities of chitinase I $\left(\mathrm{t}_{1 / 2}: 270,225,185\right.$ and 135), II ( $\mathrm{t}_{1 / 2}: 225,210,195$ and 135) and III ( $\mathrm{t}_{1 / 2}$ : $210,150,120$ and 105$)$ at $30-60^{\circ} \mathrm{C}$ respectively were observed which is greater than the chitinase of Trichoderma harzianum a recognised commercial biocontrol agent.
\end{abstract}

Keywords: chitinase, Pantoea dispersa, $\mathrm{pH}$, salts, stability, thermodynamic, temperature 


\section{Introduction}

Chitinases hydrolyze chitin, a linear polysaccharide consisting of $\beta$-(1,4)-linked $N$ acetylgucosamine (GlcNAc), which are abundant biopolymers. These enzymes are essential to chitin-containing organisms (fungi, insects, crustaceans) and used by many bacteria to utilize chitin as a source of carbon and energy [1,2]. Multiple forms of chitinases are produced to provide synergistic degradation of a complex and resilient chitin polymer for complete degradation to $N$-acetylglucosamine $[3,4,5,6]$. Chitinases of various origins possess versatile enzymological properties and are usually constituents of complex chitinolytic enzyme systems [7]. It has recently been suggested that chitinases play an important role in human diseases such as arteriosclerosis [8] and colorectal cancer [9], and its level is now considered as a diagnostic hallmark in Gaucher disease [10, 11]. Furthermore, chitinases together with proteases, glucanases and cellulases are frequently considered critical in the biocontrol of phytopathogenic fungi [12]. Chitinases occupy a unique position in agricultural biotechnology because the lytic activity inhibits fungal development by degrading chitin and glucan components of cell wall and have proven potential as antifungal agents $[13,14]$. Chitinases therefore play vital role in agricultural industries and medical fields, furthermore, chitinases also play vital roles in sea food industry for crustacean chitinous waste degradation. To accelerate identification of optimal chitinase formulations to function broadly in a range of environments for the biocontrol of phytopathogenic fungi, for cytochemical localization of chitin/chitosan using chitinase-chitosanase-gold complex, for fungal protoplast technology, for preparation of chitooligosaccharides and for degradation of chitinous waste [15], we have gained a fundamental understanding of behaviour of chitinase molecules in various conditions. For this, the study of activity and stability of chitinase enzymes in various conditions is necessary because, for example, the success of the biocontrol agent depends on geological and soil conditions where it is applied [12]. In a previous report we explained the activation of chitinase I, II and III in broad range of $\mathrm{pH}$, temperature and salts [16] as these salts were found to be significant in chitinase production using the Plackett-Burman statistical method [17]. The activity and stability of enzymes are important parameters which codetermine the economic feasibility of applying chitinase in industrial processes. High stability is generally considered an economic advantage 
because of reduced enzyme turnover [18]. A number of strategies are applied to increase the stability of chitinase enzymes such as mutation [18], chemical modification at active site $[19,20]$, introduction of disulfide bridges [21], the optimization of helices and helix caps [22], immobilization [23], entropic stabilization [24], changing $\mathrm{pH}$ condition and using various salts [25]. However, studies of chitinases in varying $\mathrm{pH}$ conditions and the effect of various salts on chitinases thermodynamic properties have not been described in the literature. Studies on the thermodynamic stability of enzymes have provided some fundamental insights into factors that determine enzyme stability [18]. Thermodynamic data for an enzyme and its catalysed reactions are essential in the prediction of the extent of reaction and the position of any process in which these reactions occur. Enzyme thermostability encompasses thermodynamic and kinetic stabilities [19]. The ability of enzyme is measured by catalysis in biochemical reactions whilst the stability of an enzyme is judged by its residual activity. Thermodynamic stability is defined by the enzyme's free energy of stabilization and its half-life $\left(t_{1 / 2}\right)$ at defined temperatures [25, 26].

Before proceeding to develop suitable chitinase enzyme formulations, accumulating information on the stability of chitinase enzymes in different conditions is necessary to ensure the economic and technical feasibility for an industrial process. Thus the present investigation utilises a thermodynamic approach (deactivation kinetics, $\Delta \mathrm{H}^{*}, \Delta \mathrm{S}^{*}, \mathrm{E}$ and $\Delta \mathrm{G}^{*}$ ) to understand the behaviour of these enzymes at different temperatures with varying $\mathrm{pH}$ and various salts. The present investigation therefore aims to understand the stability of the enzymes in the presence of a range of salts and at varying $\mathrm{pH}$, which will provide information on the activation of the enzymes after a period of stabilization. The presented thermodynamic data will aid selection of salts, their concentration and the $\mathrm{pH}$ utilised in an industrial process. 


\section{Materials and Methods}

\subsection{Chemicals}

Practical grade chitin and $N$-acetyl-D-glucosamine were purchased from Sigma Chemicals Co., (USA). All other chemicals were purchased from BDH and Fisher Chemicals (UK).

\subsection{Organism and culture conditions}

The chitinolytic bacterium was isolated from sea dumps containing crustacean wastes, in Bhavnagar, India, and was identified as $P$. dispersa [27]. The bacterium was cultivated on chitin agar medium consisting of $(\mathrm{g} / \mathrm{l})$ acid swollen chitin, 5.0; yeast extract, 0.5 ; $\left(\mathrm{NH}_{4}\right)_{2} \mathrm{SO}_{4}, 1.0 ; \mathrm{MgSO}_{4} \cdot 7 \mathrm{H}_{2} \mathrm{O}, 0.3$ and $\mathrm{KH}_{2} \mathrm{PO}_{4}, 1.36$. The $\mathrm{pH}$ of the medium was adjusted to 7.2 and sterilized by autoclaving at $121{ }^{\circ} \mathrm{C}$ for $15 \mathrm{~min}$ [28]. Acid swollen chitin was prepared by the method of Hackman [29].

\subsection{Chitinase production and purification}

A liquid medium containing (g/l) chitin, 15.0; urea, 0.32; $\mathrm{CaCl}_{2}, 0.10$ and $\mathrm{MgSO}_{4} \cdot 7 \mathrm{H}_{2} \mathrm{O}$, 0.08 was used for chitinolytic enzyme production. The $\mathrm{pH}$ of the medium was adjusted to 7.2 and sterilized by autoclaving at $121^{\circ} \mathrm{C}$ for $15 \mathrm{~min}$ [30]. A five percent inoculum of $P$. dispersa $\left(1 \times 10^{8} \mathrm{CFU} / \mathrm{ml}\right)$ was added to $50 \mathrm{ml}$ of liquid media in $250 \mathrm{ml}$ flasks and incubated for $144 \mathrm{hr}$ at $30 \pm 2{ }^{\circ} \mathrm{C}$ on a rotary shaker $(180 \mathrm{rpm})$. Subsequently the culture filtrate was collected by centrifugation at $8000 \mathrm{rpm}$ for $20 \mathrm{~min}$ and used for enzyme purification as described previously [16]. The purified chitinase I, II and III were used to study their thermalstability in presence of salts at various pH's.

\subsection{Chitinase assay}

Chitinolytic activity was assayed by the method of Vyas and Deshpande [31]. The assay system consisted of $10 \mathrm{mg}$ of acid swollen chitin, $50 \mu$ moles of acetate buffer ( $\mathrm{pH} 5)$ and $50 \mu \mathrm{l}$ of enzyme in a total volume of $3.0 \mathrm{ml}$. After incubation at $50{ }^{\circ} \mathrm{C}$ for $10 \mathrm{~min}$, products of chitinolysis were estimated by the Nelson reducing sugar method [32]. One unit of chitinolytic activity was defined as the amount of enzyme required to liberate $1 \mu$ mole of $N$-acetyl-D glucosamine equivalent at $50{ }^{\circ} \mathrm{C}$ per min. 


\subsection{Thermalstability assay}

Thermal inactivation of chitinase I, II and III were determined by incubating purified chitinase at $30,40,50$ and $60^{\circ} \mathrm{C}$. Aliquots were withdrawn at 15 min intervals, cooled on ice for $3 \mathrm{hr}$ and assayed for chitinase activity.

\subsection{Effect of salts on thermalstability}

$\mathrm{CaCl}_{2}(0.12 \mathrm{mg} / \mathrm{ml}), \mathrm{NaCl}(1.2 \mathrm{mg} / \mathrm{ml}), \mathrm{KH}_{2} \mathrm{PO}_{4}(0.06 \mathrm{mg} / \mathrm{ml}), \mathrm{KBr}(0.02 \mathrm{mg} / \mathrm{ml})$, $\mathrm{MgSO}_{4} 7 \mathrm{H}_{2} \mathrm{O}(0.02 \mathrm{mg} / \mathrm{ml}), \mathrm{NH}_{4} \mathrm{NO}_{3}(0.05 \mathrm{mg} / \mathrm{ml})$ and $\mathrm{KNO}_{3}(0.02 \mathrm{mg} / \mathrm{ml})$ were found to activate chitinase I, II and IIII [15]. Therefore the same salt concentrations were selected for the investigation of the thermalstability of these enzymes. The stability of enzymes with each salt were studied separately; initially each salt was incubated with the enzyme at $4^{\circ} \mathrm{C}$ for $10 \mathrm{~min}$. The remaining unbound salts were removed by dialysis for $1 \mathrm{hr}$ followed by thermalstability assay.

\subsection{Effect of $p H$ on thermalstability}

A pH range from 4.0 to 9.0 was selected for thermalstability of chitinase I, II and III. The $\mathrm{pH}$ of chitinase I, II and III solutions were adjusted with acetic acid (1 M) or $\mathrm{NaOH}(1$ M) followed by the thermalstability assay.

\subsection{Estimation of deactivation rate constant}

The residual activity was determined by comparing chitinase activity after heating with that of freshly prepared unheated chitinase I, II and III. The deactivation rate of these enzymes was calculated by first order expression.

$\mathrm{dE} / \mathrm{dt}=-\mathrm{K}_{\mathrm{d}} \mathrm{E}$

So that,

$\operatorname{Ln}\left[\mathrm{E}_{\mathrm{t}} / \mathrm{E}_{0}\right]=-\mathrm{K}_{\mathrm{d}} \mathrm{t}$

The $K_{d}$ (deactivation rate constant or first order rate constant) values were calculated from a plot of $\operatorname{Ln}\left[\mathrm{E}_{\mathrm{t}} / \mathrm{E}_{0}\right]$ Vs. $\mathrm{t}$ at a particular temperature.

\subsection{Estimation of thermodynamic parameters for chitinase deactivation}

In order to obtain energies and entropies of chitinase deactivation, absolute rates of reaction theory were used [33] where the rate of any reaction at a given temperature depends only on the concentration of an energy rich activated complex. Thermodynamic data were calculated by rearranging the Eyring absolute rate equation $[11,25]$.

The Eyring absolute rate equation is 
$K_{d}=\left(K_{b} T / h\right) \cdot e^{(\Delta S * / R)} \cdot e^{\left(-\Delta H^{*} / R T\right)}$

Where $\mathrm{h}($ Plank constant $)=6.63 \times 10^{-34} \mathrm{Js}, \mathrm{R}($ Gas constant $)=8.314 \mathrm{~J} / \mathrm{K} \mathrm{mol}, \Delta \mathrm{H}^{*}$ (change in enthalpy), $\Delta \mathrm{S}^{*}$ (change in entropy) and $\mathrm{K}_{\mathrm{b}}($ Boltzman constant $[\mathrm{R} / \mathrm{N}])=1.38 \mathrm{x}$ $10^{-23} \mathrm{~J} / \mathrm{K}$ where $\mathrm{N}$ (Avogadros no.) $=6.02 \times 10^{-23} \mathrm{~mol}^{-1}$

To calculate $\Delta \mathrm{H}^{*}$ and $\Delta \mathrm{S}^{*}$ the Eyring absolute rate equation is rearranged to give

$\operatorname{Ln}\left[K_{d} / T\right]=-\left(\Delta H^{*} / R\right)(1 / T)+\left(\operatorname{Ln}\left(K_{b} / h\right)+\Delta S^{*} / R\right)$

$\Delta \mathrm{H}^{*}$ and $\Delta \mathrm{S}^{*}$ values were calculated from the slope and intercept of a $\mathrm{Ln}\left[\mathrm{K}_{\mathrm{d}} / \mathrm{T}\right]$ vs. $1 / \mathrm{T}$ plot respectively.

So that,

$\Delta \mathrm{H}^{*}=-$ (slope) $\mathrm{R}$

$\Delta \mathrm{S}^{*}=\mathrm{R}\left[\right.$ intercept $\left.-\mathrm{Ln}\left(\mathrm{K}_{\mathrm{b}} / \mathrm{h}\right)\right]$

Free energy change of chitinase I, II and III were calculated by using the following relationship (16).

$\Delta \mathrm{G}^{*}=-\mathrm{RT}\left[\operatorname{Ln}\left(\mathrm{K}_{\mathrm{d}} * \mathrm{~T} / \mathrm{K}_{\mathrm{b}} * \mathrm{~h}\right)\right]$

Energy of deactivation was estimated using the Arrhenius equation

$\mathrm{K}_{\mathrm{d}}=\mathrm{A} \mathrm{e}^{(-\mathrm{E} / \mathrm{RT})}$

So that

$\operatorname{Ln}\left[\mathrm{K}_{\mathrm{d}}\right]=-\mathrm{E} / \mathrm{RT}+\mathrm{LnA}$

Energy involved in this process was calculated from the slope of a linear plot of 1/T vs. $\operatorname{Ln}\left[\mathrm{K}_{\mathrm{d}}\right][34,35]$. Thermalstability of chitinase in the presence of different salts and $\mathrm{pH}$ was determined by heating the enzyme in the presence of each salt or specified $\mathrm{pH}$ in sealed tubes for different times at $30,40,50$ and $60^{\circ} \mathrm{C}$. Enzyme activity was measured before and after incubation at respective temperature to determine residual activity under each condition.

All experiments were conducted in triplicate, results shown are mean values. 


\section{Results and Discussion}

\subsection{Deactivation rate of chitinase I, II and III in presence of salt}

Deactivation rates and half lives of purified chitinase I II and III were studied at 30, 40, 50 and $60^{\circ} \mathrm{C}$. The deactivation rate increased with increasing temperature (Fig 1) whilst the half life decreased with increasing temperature (Fig 2). The addition of $\mathrm{CaCl}_{2}$ $(0.12 \mathrm{mg} / \mathrm{ml}), \mathrm{NaCl}(1.2 \mathrm{mg} / \mathrm{ml}), \mathrm{KH}_{2} \mathrm{PO}_{4}(0.06 \mathrm{mg} / \mathrm{ml}), \mathrm{KBr}(0.02 \mathrm{mg} / \mathrm{ml}), \mathrm{MgSO}_{4} 7 \mathrm{H}_{2} \mathrm{O}$ $(0.02 \mathrm{mg} / \mathrm{ml}), \mathrm{NH}_{4} \mathrm{NO}_{3}(0.05 \mathrm{mg} / \mathrm{ml})$ and $\mathrm{KNO}_{3}(0.02 \mathrm{mg} / \mathrm{ml})$ reduced deactivation rates (Fig 1) and increased half life (Fig 2) at all temperatures studied. The effectiveness of various salts was not uniform, with the following order apparent from data: $\mathrm{NaCl}>\mathrm{KH}_{2} \mathrm{PO}_{4}>\mathrm{KBr}>\mathrm{NH}_{4} \mathrm{NO}_{3}>\mathrm{KNO}_{3}>\mathrm{MgSO}_{4} \cdot 7 \mathrm{H}_{2} \mathrm{O}>\mathrm{CaCl}_{2}$ (Fig 1, 2). This indicates that the effect of salts on stability of enzymes is related not only to the salt concentration but also to the type of salt. Chitinase I, II and III were all stabilized by salts which may be due to a reduction in unfavourable electrostatic repulsion which leads to reduced unfavourable electrostatic free energy (Table 1). Furthermore it was reported that halophilic enzymes have reduced stability in the absence of salts because they do not have sufficient hydrophobic amino acids for internal core packing [36, 37]. The stability of chitinase I, II and III were found to be optimum with $\mathrm{NaCl}$ as the deactivation rate $\left(1 / \min X 10^{-3}\right)$ of chitinase I $(2.00,2.92,4.32$, and 7.59$)$, chitinase II $(2.22,3.15,6.82$ and 8.91) and chitinase III (3.02, 5.78, 12.37 and 13.21) was comparatively higher than other salts at $30-60^{\circ} \mathrm{C}$, respectively (Fig 1). Furthermore the half life (min) of chitinase I (270, 225, 185 and 135), chitinase II (225, 210, 195 and 135) and chitinase III (210, 150, 120 and 105) were also higher than other salts at $30-60^{\circ} \mathrm{C}$, respectively (Fig 2). $\mathrm{NaCl}$ affects the electrostatic charge in halophilic enzymes and therefore increases the hydrophobic interactions which enhance protein folding and enzymatic activity [38]. It was reported that stability and activity of halophilic enzymes were usually reached only with a high salt concentration, e.g. about $3 \mathrm{M} \mathrm{KCl}$ or $\mathrm{NaCl}[39,40]$. Overall salts investigated in this study increased the stability of all three chitinase enzymes, however the salt concentrations required for optimum stability are far lower than those of halophilic enzymes. Thus, the level of salts required to enhance the stability of chitinase enzymes is significantly lower than the total salt concentration of sea water and is in the range found 
in soils [24]. High enzyme stability with a range of salts at these lower concentrations will therefore increase the efficacy of use under variable environmental conditions.

\subsection{Deactivation rate of chitinase I, II and III at varying $\mathrm{pH}$}

$\mathrm{pH}$ is one of the main factors affecting tertiary and quaternary structures of proteins and enzymes. In many cases the rate of deactivation depends on the $\mathrm{pH}$ of the enzyme solution [26]. Deactivation rates and half lives of chitinase I, II and III were studied at 30, 40, 50 and $60^{\circ} \mathrm{C}$ with varying $\mathrm{pH}$ conditions. A $\mathrm{pH}$ range from 4 to 9 was selected, enzymes were found to have optimum activity at pH 5 [30]. However, the data (Fig 3,4) shows that all three enzymes have greater stability at alkaline $\mathrm{pH}$ 's indeed the order of stability in varying $\mathrm{pH}$ was as follows: $9 \geq 8>7>6>5>4$. At higher $\mathrm{pH}$ 's the folding of chitinase enzymes may relax due to changes in the balance of electrostatic and hydrogen bonds which resulted in increased stability $[25,26]$. Chitinase II was found to have a slightly lower deactivation rate and slightly higher half life than chitinase I and III across the $\mathrm{pH}$ range studied indicating that chitinase II has slightly greater stability over broad $\mathrm{pH}$ range than chitinase I and III.

The optimum stability of chitinase I, II and III were found at alkaline pH's. At pH 8 the deactivation rates $\left(1 / \min X 10^{-3}\right)$ of chitinase I $(1.3,2.2,3.5$ and 4.7$)$, chitinase II $(2.5,2.8$, 4.0 and 5.1) and chitinase III $(1.5,2.9,4.0$ and 6.4$)$ were observed at $30-60^{\circ} \mathrm{C}$, respectively. The following half lives $(\mathrm{min})$ of chitinase I $(270,225,185$ and 135), chitinase II $(225,210,195$ and 135) and chitinase III (210, 150, 120 and 105) were observed at $30-60^{\circ} \mathrm{C}$, respectively. All these chitinases proved to be significantly more stable than the chitinase enzyme of Trichoderma harzianum $\left(\mathrm{k}_{\mathrm{d}}: 0.0608,0.0905\right.$ and $0.13971 / \mathrm{min})\left(\mathrm{t}_{1 / 2}: 11.41,7.61\right.$ and $\left.4.96 \mathrm{~min}\right)$.

Further to the deactivation study, an investigation of other thermodynamics parameters $\left(\Delta \mathrm{H}^{*}, \Delta \mathrm{S}^{*}, \Delta \mathrm{G}^{*}\right.$ and activation energy) is necessary to understand the behaviour of molecules in different physiological conditions. The numerical values of thermodynamic properties are affected by two factors, namely solvent effect due to presence of surrounding water molecules and structural effect due to conformational changes occurring in the enzyme molecule during reaction. 


\subsection{Enthalpy and activation energy change of chitinase I, II and III deactivation in}

presence of salts and varying $\mathrm{pH}$ 's

Thermal denaturation of enzymes occurs in two steps i.e. $\mathrm{N} \leftrightarrow \mathrm{U} \rightarrow \mathrm{I}$, where $\mathrm{N}$ is native enzyme, $U$ is unfolded inactive enzyme which could be reversibly refolded upon cooling and $\mathrm{I}$ is inactivated enzyme formed after prolonged exposure to heat and therefore can not be recover upon cooling [41].

Enthalpy change and deactivation energy of chitinase I, II and III were calculated within a temperature range of 30 to $60^{\circ} \mathrm{C}$ in the presence of each salt and varying $\mathrm{pH}$ (Table 2). It has been reported that enthalpy change of enzymes should be in the range of 20 to 150 $\mathrm{kJ} / \mathrm{mol}$ [42]. $\Delta \mathrm{H}^{*}$ of chitinase I, II and III deactivation was within this range in the presence of each salt at $\mathrm{pH} 8$ which indicates that these enzymes maintained their rate of reaction even during incubation at different temperatures. Furthermore enthalpy of chitinase I, II and III increased as $\mathrm{pH}$ increased (Table 2). However the enthalpy change of chitinase I and II were below $20 \mathrm{~kJ} / \mathrm{mol}$ at $\mathrm{pH} \mathrm{4,} 5$ and 6 but above $20 \mathrm{~kJ} / \mathrm{mol}$ at $\mathrm{pH} 7$, 8 and 9. This result indicates that chitinase I and II were more stable at alkaline pH's whereas the enthalpy change of chitinase III was greater than $20 \mathrm{~kJ} / \mathrm{mol}$ at $\mathrm{pH} 4$ to 9 indicating a broader range of $\mathrm{pH}$ stability. Overall enthalpy increased with increasing $\mathrm{pH}$ as well as the addition of each salt indicating that chitinase I, II and III have some degree of conformational flexibility in the presence of each salt and varying $\mathrm{pH}$ due to increasing hydrophobic interactions. A decrease in deactivation energy of chitinase I, II and III with each salt and increasing $\mathrm{pH}$ was observed (Table 2).

\subsection{Entropy change of chitinase deactivation in presence of salts and $\mathrm{pH}$}

In all cases, entropy changes were found to be negative. Negative entropy is found in biocatalytic systems due to compaction of enzyme molecules, but equally such changes could arise from formation of charged particles, associated gains and ordering of solvent molecules [43]. Furthermore the transition states of the chitinases were found to be ordered as revealed by negative $\Delta S^{*}$ (Table 2). Similar results have been observed for the amylase of Bacillus lichiniformis [44] and the chitinase of Trichoderma harzianum [25]. Enzymes could be made more thermostable by either stabilizing native form, by putting non covalent bonds including hydrogen bonds, salt-bridges and hydrophobic interactions or by decreasing the entropy of unfold [45]. Similarly results were obtained by addition 
of each salt in chitinase I, II and III, $\Delta \mathrm{S}^{*}$ was comparatively lower for all three chitinases in the presence of each salt when compared to untreated chitinase I, II and III (Table 2). It has also been reported that thermalstabilization of enzymes is often accompanied by a decrease in $\Delta \mathrm{S}^{*}$ and disulfide bridges which are believed to stabilize proteins mostly through an entropic effect, by decreasing the entropy of the protein's unfolded state [45, 46]. $\Delta \mathrm{S}^{*}$ was comparatively lower than untreated chitinase I, II and III. This result indicates that chitinases were altered in the direction of partially unfolded transition state but the flexibility implies decreased conformational entropy of the folded state which is favourable to thermodynamic stability.

\subsection{Free Energy change of chitinase deactivation in presence of salts and $\mathrm{pH}$}

For all three chitinase enzymes, $\Delta \mathrm{G}^{*}$ increased with increasing temperature. However, this was a comparatively smaller increase than previously reported chitinase of Trichoderma harzianum [25]. There was a significant decrease in the $\Delta \mathrm{G}^{*}$ value with increasing $\mathrm{pH}$ (Table 1). Voordouw et al. [43] proposed that kinetic thermalstability should be used for defining thermostable enzymes. In addition, these authors emphasize that resistance of enzymes to thermal denaturation is due to the 'intrinsic' contribution of the polypeptide chain (i.e. hydrophobic interactions, hydrogen bonding and ionic stabilization).

To assess the contribution of various ions to thermalstabilization of chitinase, the effect of each salt at its optimum activation concentration on thermalstability of enzymes was studied at 30 to $60{ }^{\circ} \mathrm{C}$. Free energy of chitinase I, II and III decreased with each salt indicating that thermalstability of the chitinases was dependent on interactions with the salts, with the following order of decrease in free energy observed: $\mathrm{NaCl}>\mathrm{KH}_{2} \mathrm{PO}_{4}>\mathrm{KBr}>\mathrm{NH}_{4} \mathrm{NO}_{3}>\mathrm{KNO}_{3}>\mathrm{MgSO}_{4} \cdot 7 \mathrm{H}_{2} \mathrm{O}>\mathrm{CaCl}_{2}$ (Table 1). Similar results were also obtained in varying $\mathrm{pH}$ conditions with the following order $9 \geq 8>7>6>5>4$ found (Table 2) It has been reported that the mechanism by which salts, affect enzyme stability may be explained by the effect of salt on water structure and hence on the strength of hydrophobic interactions [35].

The data presented provides essential information for the optimal application of the chitinase enzymes for various purposes. The thermodynamic properties of the enzymes described here show that chitinase I, III and III of $P$. dispersa exhibit enhanced stability 
in the presence of salts and alkaline $\mathrm{pH}$ which may be a useful attribute to utilise when applied as a biocontrol agent in heterogeneous environments or for industrial and laboratory chitin degradation processes.

\section{References}

[1] E.Sándor, T. Pusztahelyi, L.Karaffa, Z. Karányi, I. Pócsi, B. Sándor, A. Szentirmai, I. Pócsi, Allosamidin inhibits the fragmentation of Acremonium chrysogenum but does not influence the cephalosporin-C production of the fungus. FEMS Microbiol. Lett. 164 (1998) 231-236.

[2] D.M.F. van Aalten, D. Komander, B. Synstad, S. Gaseidnes, M.G. Peter, V.G.H. Eijsink, Structural insights into the catalytic mechanism of a family 18 exo-chitinase. Proc. Natl. Acad. Sci. USA 98 (2001) 8979-8984.

[3] T. Watanabe, W. Oyanagi, K. Suzuki, H. Tanaka, Chitinase system of Bacillus circulans WL-12 and importance of chitinase A1 in chitin degradation. J. Bacteriol. 172 (1990) 4017-4022.

[4] K. Sakai, A. Yokota, H. Kurokawa, M. Wakayama, M. Moriguchi, Purification and characterization of three thermostable endochitinases of a noble Bacillus strain, $\mathrm{MH}-$ 1, isolated from chitin-containing compost. Appl. Environ. Microbiol. 64 (1998) 3397-3402.

[5] K. Mavromatis, M. Lorito, S.L. Woo, V. Bouriotis, Mode of action and antifungal properties of two cold-adapted chitinases. Extremophiles 7(2003) 385-390.

[6] M.V. Deshpande, Enzymatic degradation of chitin and its biological applications. J. Sci. Ind. Res. 45 (1986) 273-281.

[7] T. Fukamizo, Chitinolytic Enzymes catalysis, substrate binding, and their application. Curr. Prot. Pept. Sci. 1 (2000) 105-124.

[8] R.G. Boot, T.A. van Achterberg, B.E. van Aken, G.H. Renkema, M.J. Jacobs, J.M. Aerts, C.J. de Vries, Strong induction of members of the chitinase family of proteins in atherosclerosis: chitotriosidase and human cartilage gp-39 expressed in lesion macrophages. Arterioscler. Thromb. Vasc. Biol. 19 (1999) 687-694.

[9] C. Cintin, J.S. Johasen, I.J. Christensen, P.A. Price, S. Sorensen, H.J. Nielsen, Serum YKL-40 and colorectal cancer. Br. J. Cancer 79 (1999) 1494-1499. 
[10] C.E. Hollak, S. van Weely, M.H. van Oers, J.M. Aerts, Marked elevation of plasma chitotriosidase activity. A novel hallmark of Gaucher disease. J. Clin. Invest. 93 (1994) 1288-1292.

[11] S. Cottaz, B.Brasme, H. Driguez, A fluorescence-quenched chitopentaose for the study of endo-chitinases and chitobiosidases. Eur. J. Biochem. 267 (2000) 5593-5600.

[12] V. Gohel, A. Singh, V. Maisuria, A. Phadnis, H.S. Chhatpar, Bioprospecting and antifungal potential of chitinolytic microorganisms. Afr. J. Biotechnol. 5 (2006) 5472 .

[13] W.J. Jung, J.H. Kuk, K.Y. Kim, T.H. Kim, R.D. Park, Purification and characterization of chitinase from Paenibacillus illinoisensis KJA-424. J. Microbiol. Biotechnol. 15 (2005) 274-280.

[14] Z.K. Punja, Y.Y. Zhang, Plant chitinases and their roles in resistance to fungal diseases. J. Nematol. 25 (1993) 526-540.

[15] R. Vaidya, P. Vyas, H. S. Chhatpar, Statistical optimization of medium components for the production of chitinase by Alcaligenes xylosoxydans. Enzyme Microbial Technol. 33 (2003) 92-96.

[16] V. Gohel, and D. C. Naseby, Novel chitinolytic enzymes of the marine bacterium Pantoea dispersa. Submitted to J. Biol. Chem. (2006) under subscription number M6:06269.

[17] V. Gohel, T. Chaudhary, P. Vyas, H. S. Chhatpar, Statistical screening of medium components for the production of chitinase by the marine isolate Pantoea dispersa. Biochem. Eng. J. 28 (2006), 50-56.

[18] C. Vieille, G. J. Zeikus, Hyperthermophilic enzymes: sources, uses, and molecular mechanisms for thermostability. Microbiol. Mol. Biol. Rev. 65 (2001) 1-43.

[19] S. Gåseidnes, B. Synstad, X. Jia, H. Kjellesvik, G. Vriend, V.G.H. Eijsink, Stabilization of a chitinase from Serratia marcescens by Gly $\rightarrow$ Ala and $\mathrm{Xxx} \rightarrow$ Pro mutations. Protein Eng. 16 (2003) 841-846.

[20] J. Mansfeld, G. Vriend, B.W. Dijkstra, O.R. Veltman, B. Van den Burg, G. Venema, R. Ulbrich-Hofmann, V.G.H. Eijsink, Extreme stabilization of a thermolysin-like protease by an engineered disulfide bond. J. Biol. Chem. 272 (1997) 11152-11156. 
[21] M.H. Rashid, K.S. Siddiqui, Thermodynamic and kinetic study of stability of the native and chemically modified $\beta$-glucosidases from Aspergillus niger. Proc. Biochem. 33 (1998) 109-115.

[22] M. Blaber, X.J. Zhang, B.W. Matthews, Structural basis of amino acid alpha helix propensity. Science 260 (1993) 1637-1640.

[23] J. P. Chen, K. C. Chang, Immobilization of chitinase on a reversibly solubleinsoluble polymer for chitin hydrolysis. J. Chem. Technol. Biotechnol. 60 (1994) 133-140.

[24] B.W. Matthews, H. Nicholson, W.J. Becktel, Enhanced protein thermostability from site-directed mutations that decrease the entropy of unfolding Proc. Natl. Acad. Sci. USA 84 (1987) 6663-6667.

[25] A. Kapat, T. Panda, $\mathrm{pH}$ and thermal stability studies of chitinase from Trichoderma harzianum: A thermodynamic consideration Biopro. Biosys. Eng. 16 (1997) 269 272.

[26] R. Srinivas, T. Panda, Enhancing the feasibility of many biotechnological processes through enzyme deactivation studies. Biopro. Eng. 21 (1999) 363-369.

[27] V. Gohel, T. Chaudhary, P. Vyas, H.S. Chhatpar, Isolation and identification of marine chitinolytic bacteria and their potential in antifungal biocontrol. Indian J. Exp. Biol. 42 (2004) 715-720.

[28] J. Monreal, E.T. Reese, The chitinase of Serratia marcescens. Can. J. Microbiol. 15 (1969) 689-696.

[29] R.H. Hackman, Studies on Chitin V: The action of mineral acids on chitin Aus. J. Biol. Sci. 15 (1962) 526-537.

[30] V. Gohel, S. Trivedi, P. Vyas, H.S. Chhatpar Formulation of medium constituents by multiresponse analysis of central composite design to enhance chitinase production in Pantoea dispersa. Indian J. Exp. Biol. 42 (2004) 1131-1123.

[31] P. Vyas, M.V. Deshpande, Chitinase production by Myrothecium verrucaria and its significance for fungal mycelia degradation. J. Gen. Appl. Microbiol. 35 (1989) $343-350$

[32] N. Nelson, A photometric adaptation of the Somogyii method for the determination of glucose. J. Biol. Chem. 153 (1994) 375-380 
[33] H. Eyring, A.E. Stearn, The application of the theory of absolute reaction rates to proteins. Chem. Rev. 24 (1939) 253-270.

[34] K. J. Laidler, B. F. Peterman, Temperature effects in enzyme kinetics. Methods Enzymol. 63 (1979) 234-257.

[35] J. G. M. Francisco, C.A.O. Maria, M. R. Angel, Further thermal characterization of an aspartate aminotransferase from a halophilic organism. Biochem. J. 298 (1994) 465-470.

[36] P. Milan, V. Peter, Analysis of the mechanism and kinetics of thermal inactivation of enzymes: Critical assessment of isothermal inactivation experiments. Proc. Biochem. 31 (1996) 787-800.

[37] T.S-B. Lee, K. Inouye, B. Tonomura, The states of tyrosyl rsidues in thermolysin as examined by nitration and pH-dependent ionization. J. Biochem. 121 (1997) 231237.

[38] T. Arakawa, and M. Tokunaga, Electrostatic and hydrophobic interactions play a major role in the stability and refolding of halophilic proteins. Protein Pept. Lett. 11 (2004) 125-32.

[39] I. Kuniyo, K. Keiko, B. Tonomura, Sodium chloride enhances markedly the thermal stability of thermolysin as well as its catalytic activity. Biochim. Biophys. Acta 1388 (1998) 209-214.

[40] G. Zaccai, H. Eisenberg, Halophilic proteins and the influence of solvent on protein stabilization. Trends Biochem. Sci. 15 (1990) 333-337.

[41] H. Eisenberg, M. Mevarech, G. Zaccai, Biochemical, structural, and molecular genetic aspects of halophilism. Adv. Protein Chem. 43 (1992) 1-62.

[42] S. D’Amico, J-C. Marx, C. Gerday, G. Feller Activity-Stability Relationships in Extremophilic Enzymes. J. Biol. Chem. 278 (2003) 7891-7896.

[43] G. Voordouw, C. Milo, R. S. Roche, Further thermal characterization of an aspartate aminotransferase from a halophilic organism. Biochem. 15 (1976) 3716-3723.

[44] R.L. Foster, Modification of enzyme activity. The nature of enzymology, Baron, P.J. ed., Croom Helm, London, 1980, pp. 91-161. 
[45] N. Declerck, M. Machius, P. Joyet, G. Wiegand, R. Huber, C. Gaillardin, Hyperthermostabilization of Bacillus licheniformis $x$-amylase and modulation of its stability over a $50^{\circ} \mathrm{C}$ temperature range. Protein Eng. 16 (2003) 287-293.

[46] M. Matsumura, G. Signor, B. W. Matthews, Substantial increase of protein stability by multiple disulfide bonds. Nature 342 (1989) 291-293.

\section{Acknowledgements}

We sincerely acknowledge the Commonwealth Commission Scholarship \& Fellowship Plan (CSFP), British Council UK for their financial support. 
Table 1 Values of $\Delta \mathrm{G}^{*}$ for deactivation of chitinase I, II and III

\begin{tabular}{|c|c|c|c|c|}
\hline \multirow[t]{3}{*}{ Enzyme system } & \multicolumn{4}{|c|}{$\Delta \mathrm{G}^{*}(\mathrm{~kJ} / \mathrm{mol})$ for deactivation of chitinases } \\
\hline & $30^{\circ} \mathrm{C}$ & & $50^{\circ} \mathrm{C}$ & $60^{\circ} \mathrm{C}$ \\
\hline & $(303.15 \mathrm{~K})$ & $(313.15 \mathrm{~K})$ & $(323.15 \mathrm{~K})$ & $(333.15 \mathrm{~K})$ \\
\hline Chitinase I & 87.98 & 90.68 & 92.07 & 93.81 \\
\hline Chitinase $\mathrm{I}+\mathrm{CaCl}_{2}$ & 85.67 & 87.88 & 88.90 & 90.28 \\
\hline Chitinase $\mathrm{I}+\mathrm{NaCl}$ & 78.96 & 80.97 & 81.90 & 84.31 \\
\hline Chitinase $\mathrm{I}+\mathrm{KH}_{2} \mathrm{PO}_{4}$ & 80.59 & 82.90 & 81.22 & 85.63 \\
\hline Chitinase I + KBr & 82.99 & 84.10 & 83.98 & 86.80 \\
\hline Chitinase $\mathrm{I}+\mathrm{MgSO}_{4} 7 \mathrm{H}_{2} \mathrm{O}$ & 84.07 & 85.70 & 86.35 & 87.06 \\
\hline Chitinase $\mathrm{I}+\mathrm{KNO}_{3}$ & 83.88 & 85.21 & 86.93 & 87.57 \\
\hline Chitinase I $+\mathrm{NH}_{4} \mathrm{NO}_{3}$ & 83.26 & 85.53 & 81.85 & 87.44 \\
\hline Chitinase I + pH 4 & 85.13 & 86.92 & 89.33 & 92.41 \\
\hline Chitinase I + pH 5 & 84.84 & 85.66 & 88.01 & 90.85 \\
\hline Chitinase I + pH 6 & 83.66 & 84.65 & 85.66 & 88.22 \\
\hline Chitinase I + pH 7 & 82.41 & 83.03 & 84.11 & 85.87 \\
\hline Chitinase $\mathrm{I}+\mathrm{pH} 8$ & $80 . .31$ & 81.88 & 82.45 & 84.61 \\
\hline Chitinase I + pH 9 & 80.73 & 82.81 & 83.45 & 84.55 \\
\hline Chitinase II & 87.74 & 89.91 & 90.36 & 92.19 \\
\hline Chitinase $\mathrm{II}+\mathrm{CaCl}_{2}$ & 87.64 & 88.26 & 89.98 & 91.71 \\
\hline Chitinase II + NaCl & 81.69 & 83.78 & 84.70 & 85.87 \\
\hline Chitinase II $+\mathrm{KH}_{2} \mathrm{PO}_{4}$ & 82.63 & 84.37 & 85.66 & 87.39 \\
\hline Chitinase II + KBr & 84.68 & 87.96 & 88.14 & 89.49 \\
\hline Chitinase II $+\mathrm{MgSO}_{4} 7 \mathrm{H}_{2} \mathrm{O}$ & 86.80 & 88.19 & 89.51 & 91.67 \\
\hline Chitinase II + $\mathrm{KNO}_{3}$ & 86.65 & 88.94 & 89.56 & 90.25 \\
\hline Chitinase II $+\mathrm{NH}_{4} \mathrm{NO}_{3}$ & 85.64 & 88.70 & 89.45 & 90.24 \\
\hline Chitinase II + pH 4 & 84.77 & 87.63 & 90.01 & 91.60 \\
\hline Chitinase II + pH 5 & 83.96 & 86.86 & 89.19 & 89.85 \\
\hline Chitinase II + pH 6 & 81.31 & 87.94 & 88.30 & 88.90 \\
\hline Chitinase II + pH 7 & 80.71 & 85.89 & 87.58 & 88.36 \\
\hline Chitinase II + pH 8 & 79.71 & 82.07 & 84.11 & 86.39 \\
\hline Chitinase II + pH 9 & 80.01 & 82.99 & 84.66 & 86.45 \\
\hline Chitinase III & 87.41 & 89.70 & 90.04 & 92.11 \\
\hline Chitinase III $+\mathrm{CaCl}_{2}$ & 85.37 & 87.20 & 89.19 & 91.25 \\
\hline Chitinase III + NaCl & 80.93 & 82.24 & 83.14 & 84.79 \\
\hline Chitinase III $+\mathrm{KH}_{2} \mathrm{PO}_{4}$ & 81.32 & 83.84 & 84.16 & 85.84 \\
\hline Chitinase III + KBr & 82.99 & 84.20 & 86.53 & 88.58 \\
\hline Chitinase III $+\mathrm{MgSO}_{4} 7 \mathrm{H}_{2} \mathrm{O}$ & 84.03 & 86.72 & 88.90 & 90.57 \\
\hline Chitinase III $+\mathrm{KNO}_{3}$ & 83.77 & 85.58 & 87.56 & 89.24 \\
\hline Chitinase III $+\mathrm{NH}_{4} \mathrm{NO}_{3}$ & 83.31 & 85.80 & 86.88 & 89.24 \\
\hline Chitinase III + pH 4 & 84.59 & 87.48 & 89.59 & 90.28 \\
\hline Chitinase III + pH 5 & 83.16 & 86.66 & 88.50 & 89.90 \\
\hline Chitinase III + pH 6 & 82.99 & 85.86 & 86.16 & 87.22 \\
\hline Chitinase III + pH 7 & 81.41 & 83.44 & 84.92 & 85.34 \\
\hline Chitinase III + pH 8 & 80.97 & 81.99 & 82.08 & 83.77 \\
\hline Chitinase III + pH 9 & 81.51 & 82.40 & 83.16 & 84.85 \\
\hline
\end{tabular}


Table 2 Values of $\Delta \mathrm{H}^{*}, \Delta \mathrm{S}^{*}$ and activation energy for chitinase I, II and III deactivation in presence of salts and $\mathrm{pH}$ (temperature range from $30^{\circ} \mathrm{C}$ to $60^{\circ} \mathrm{C}$ )

\begin{tabular}{|c|c|c|c|}
\hline Enzyme system & $\begin{array}{l}\Delta \mathrm{H}^{*} \\
(\mathrm{~kJ} / \mathrm{mol})\end{array}$ & $\begin{array}{l}\Delta \mathrm{S}^{*} \\
(\mathrm{~J} / \mathrm{mol} \mathrm{K})\end{array}$ & $\begin{array}{l}\mathrm{E} \\
(\mathrm{kJ} / \mathrm{mol})\end{array}$ \\
\hline Chitinase I & 29.24 & -53.38 & 50.96 \\
\hline Chitinase $\mathrm{I}+\mathrm{CaCl}_{2}$ & 37.54 & -58.63 & 36.19 \\
\hline Chitinase I + NaCl & 33.01 & -60.33 & 35.73 \\
\hline Chitinase $\mathrm{I}+\mathrm{KH}_{2} \mathrm{PO}_{4}$ & 36.27 & -59.24 & 38.74 \\
\hline Chitinase I + KBr & 39.93 & -58.11 & 42.40 \\
\hline Chitinase $\mathrm{I}+\mathrm{MgSO}_{4} 7 \mathrm{H}_{2} \mathrm{O}$ & 33.46 & -59.80 & 35.93 \\
\hline Chitinase $\mathrm{I}+\mathrm{KNO}_{3}$ & 36.60 & -59.98 & 39.08 \\
\hline Chitinase I $+\mathrm{NH}_{4} \mathrm{NO}_{3}$ & 46.48 & -56.14 & 48.95 \\
\hline Chitinase I + pH 4 & 8.83 & -67.36 & 10.68 \\
\hline Chitinase I + pH 5 & 12.84 & -66.26 & 14.69 \\
\hline Chitinase I + pH 6 & 17.68 & -64.66 & 19.52 \\
\hline Chitinase I + pH 7 & 29.26 & -61.43 & 31.10 \\
\hline Chitinase I + pH 8 & 34.45 & -60.34 & 35.56 \\
\hline Chitinase I + pH 9 & 38.78 & -58.99 & 40.63 \\
\hline Chitinase II & $24 . .31$ & -55.57 & 47.82 \\
\hline Chitinase II $+\mathrm{CaCl}_{2}$ & 40.84 & -56.85 & 41.36 \\
\hline Chitinase II $+\mathrm{NaCl}$ & 33.71 & -60.02 & 36.18 \\
\hline Chitinase II $+\mathrm{KH}_{2} \mathrm{PO}_{4}$ & 33.45 & -59.82 & 35.92 \\
\hline Chitinase II + KBr & 21.40 & -59.61 & 37.18 \\
\hline Chitinase II $+\mathrm{MgSO}_{4} 7 \mathrm{H}_{2} \mathrm{O}$ & 34.58 & -59.36 & 37.05 \\
\hline Chitinase $\mathrm{II}+\mathrm{KNO}_{3}$ & 26.76 & -61.43 & 29.23 \\
\hline Chitinase II $+\mathrm{NH}_{4} \mathrm{NO}_{3}$ & 40.74 & -57.07 & 41.12 \\
\hline Chitinase II + pH 4 & 13.46 & -72.59 & 16.04 \\
\hline Chitinase II + pH 5 & 13.38 & -66.15 & 15.97 \\
\hline Chitinase II + pH 6 & 16.33 & -65.27 & 18.91 \\
\hline Chitinase II + pH 7 & 28.04 & -61.99 & 30.62 \\
\hline Chitinase II + pH 8 & 30.33 & -65.33 & 33.45 \\
\hline Chitinase II + pH 9 & 32.88 & -60.83 & 40.19 \\
\hline Chitinase III & 22.32 & -56.31 & 48.62 \\
\hline Chitinase III $+\mathrm{CaCl}_{2}$ & 24.44 & -60.96 & 40.19 \\
\hline Chitinase III + NaCl & 34.05 & -59.53 & 36.52 \\
\hline Chitinase III $+\mathrm{KH}_{2} \mathrm{PO}_{4}$ & 22.10 & -58.55 & 24.69 \\
\hline Chitinase III + KBr & 27.48 & -61.38 & 29.26 \\
\hline Chitinase III $+\mathrm{MgSO}_{4} 7 \mathrm{H}_{2} \mathrm{O}$ & 28.52 & -61.44 & 30.99 \\
\hline Chitinase III + $\mathrm{KNO}_{3}$ & 27.76 & -61.19 & 30.43 \\
\hline Chitinase $\mathrm{III}+\mathrm{NH}_{4} \mathrm{NO}_{3}$ & 38.80 & -58.30 & 41.27 \\
\hline Chitinase III + pH 4 & 15.23 & -74.03 & 17.81 \\
\hline Chitinase III + pH 5 & 25.38 & -62.25 & 27.94 \\
\hline Chitinase III + pH 6 & 28.41 & -60.66 & 30.42 \\
\hline Chitinase III + pH 7 & 32.14 & -59.01 & 36.42 \\
\hline Chitinase III + pH 8 & 35.87 & -59.70 & 38.45 \\
\hline Chitinase III + pH 9 & 38.34 & -60.83 & 40.89 \\
\hline
\end{tabular}


Fig 1 Deactivation rate of chitinase I (a); chitinase II (b) and chitinase III (c) in presence of salts control; $2 \mathrm{~m} \quad \mathrm{CaCl}_{2}(0.12 \mathrm{mg} / \mathrm{ml})$; $\mathrm{NaCl}(1.2 \mathrm{mg} / \mathrm{ml}) ; \square \mathrm{KH}_{2} \mathrm{PO}_{4}(0.08 \mathrm{mg} / \mathrm{ml}) ;$ $\mathrm{KBr}(0.02 \mathrm{mg} / \mathrm{ml}) ; \square \mathrm{MgSO}_{4} 7 \mathrm{H}_{2} \mathrm{O}(0.02 \mathrm{mg} / \mathrm{ml}) ; \mathrm{KNO}_{3}(0.02 \mathrm{mg} / \mathrm{ml})$; and 血血 $\mathrm{NH}_{4} \mathrm{NO}_{3}(0.005 \mathrm{mg} / \mathrm{ml})$

Fig 2 Half life ( $\left.\mathrm{t}_{1 / 2}\right)$ of chitinase I (a); chitinase II (b) and chitinase III (c) in presence of salts control; $2 \mathrm{CaCl}_{2}(0.12 \mathrm{mg} / \mathrm{ml})$; $\mathrm{NaCl}(1.2 \mathrm{mg} / \mathrm{ml}) ; \square \mathrm{KH}_{2} \mathrm{PO}_{4}(0.08 \mathrm{mg} / \mathrm{ml})$;

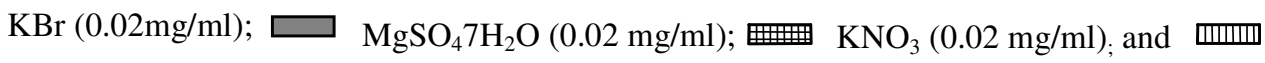
$\mathrm{NH}_{4} \mathrm{NO}_{3}(0.005 \mathrm{mg} / \mathrm{ml})$

Fig 3 Deactivation rate of chitinase I (a); chitinase II (b) and chitinase III (c) at varying pH pH 4 ए

Fig 4 Half life $\left({ }_{t 1 / 2}\right)$ of chitinase I (a); chitinase II (b) and chitinase III (c) at varying $\mathrm{pH}$

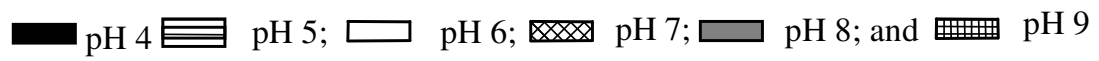


Fig 1
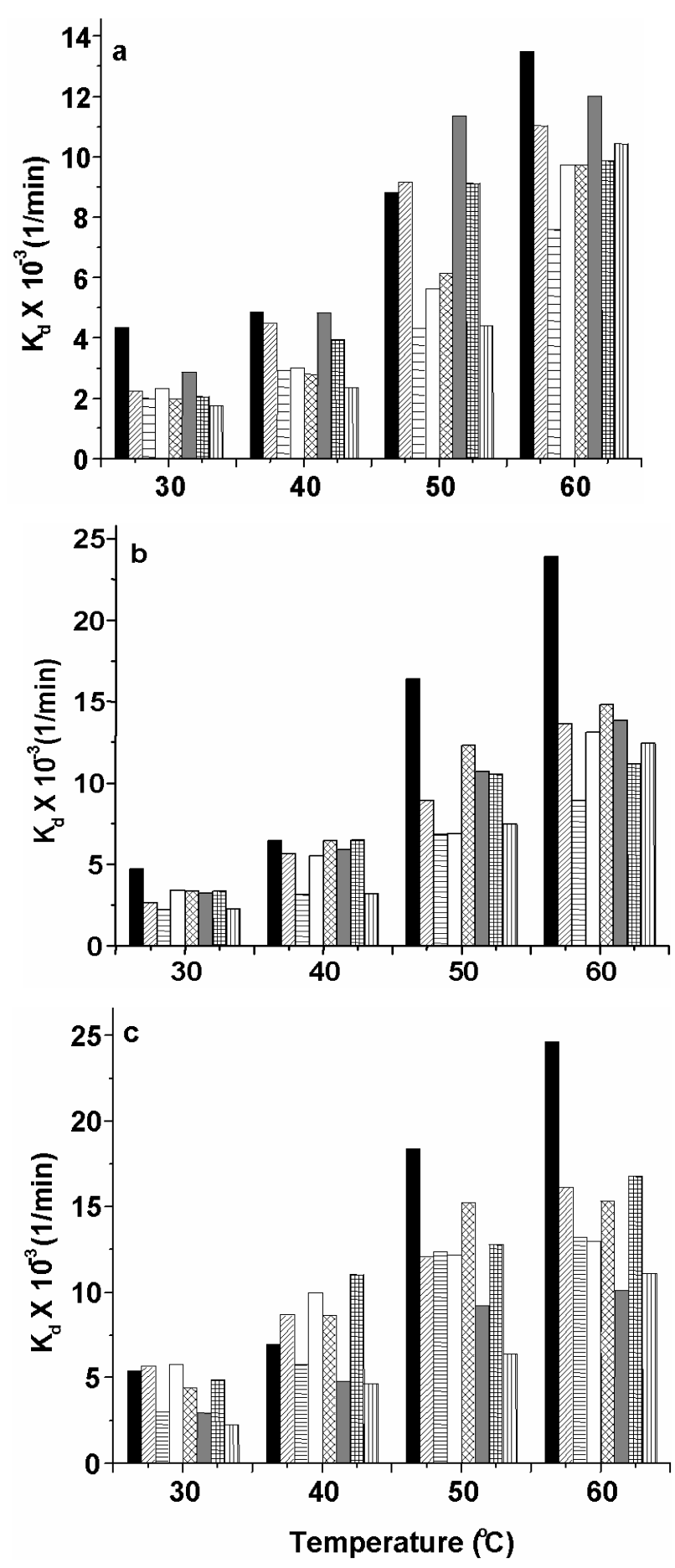
Fig 2
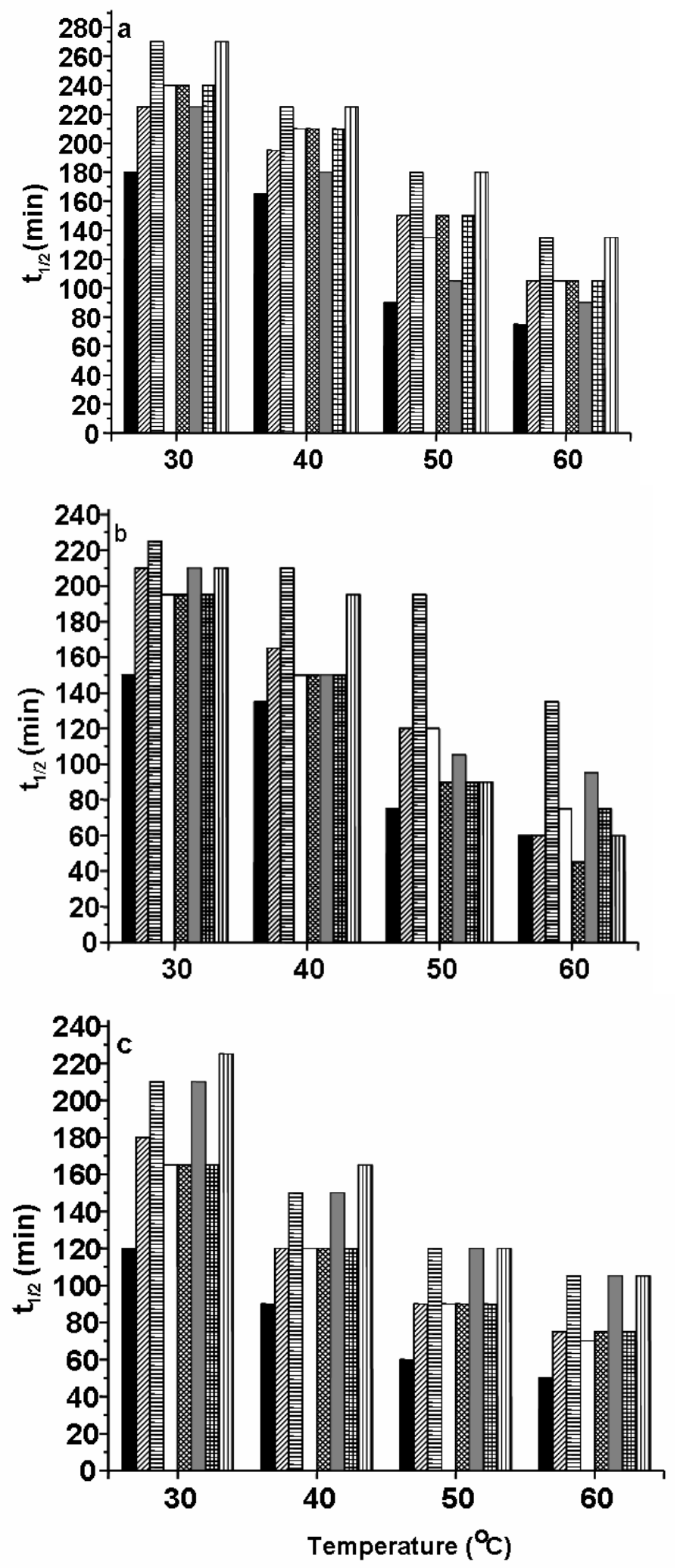
Fig 3
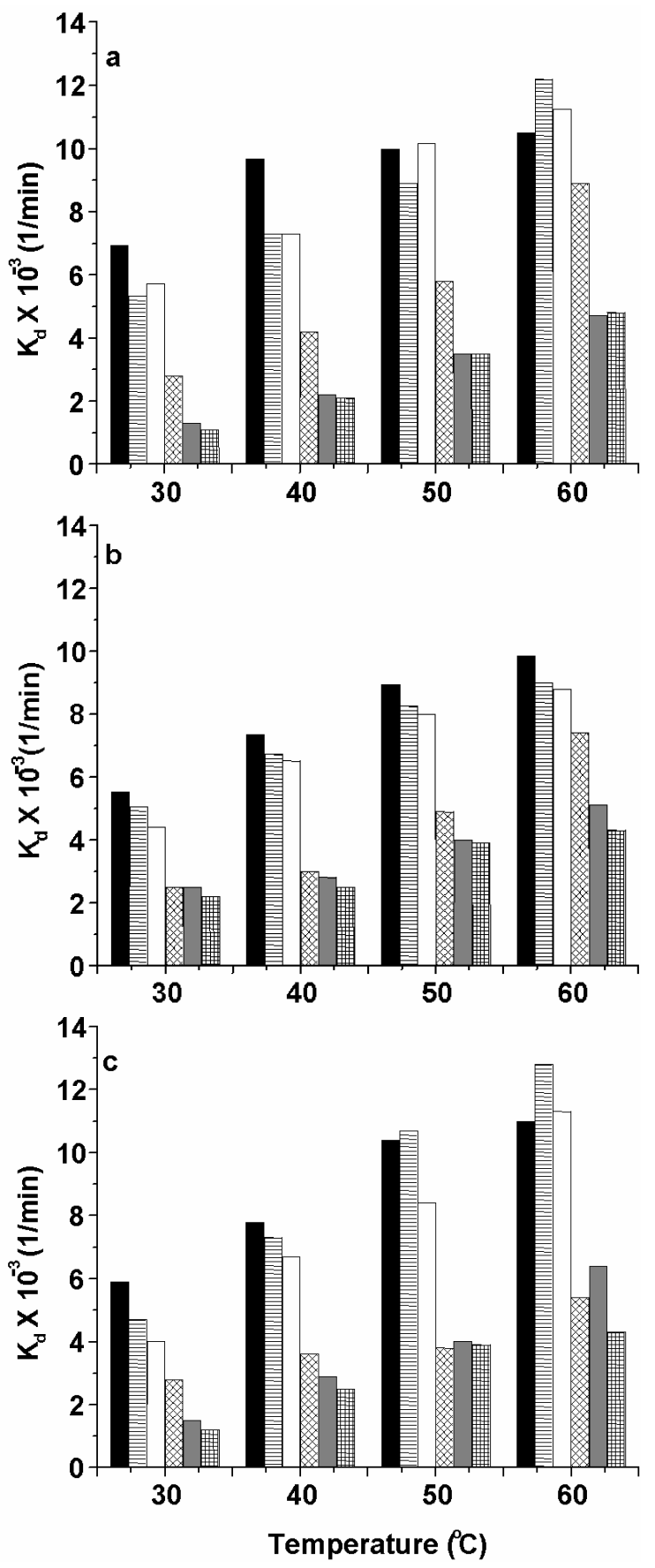
Fig 4
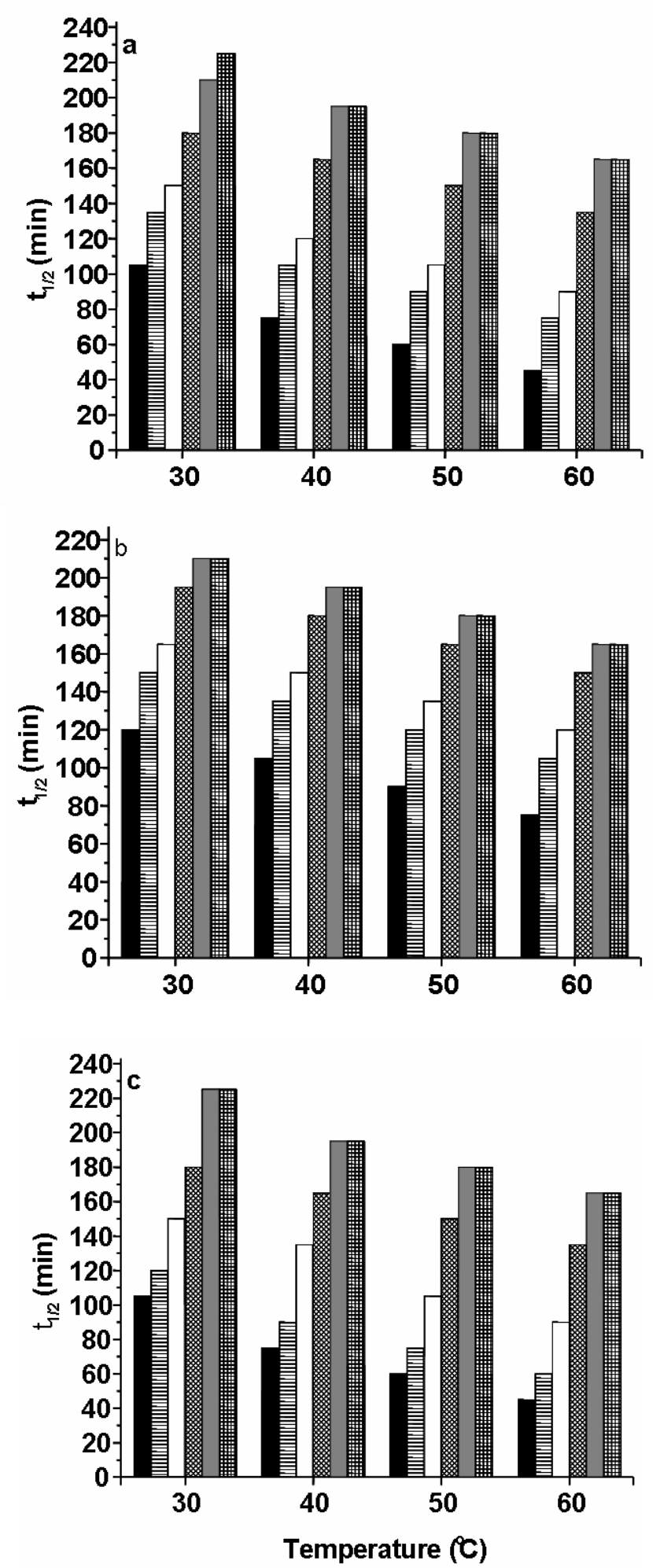